\title{
Exploitation of Heterotic Combinations for Grain Yield and Yield Associated Components in Kharif Sorghum
}

\author{
Vikas Mangal, R.B. Ghorade*, Dipali P. Thakare, V.V. Kalpande and A.M. Dange
}

All India Coordinated Sorghum Improvement Project, Akola Centre, Sorghum Research Unit, Dr. Panjabrao Deshmukh Krishi Vidyapeeth, Akola - 444104 (M.S.), India

*Corresponding author

\section{A B S T R A C T}

\section{Keywords}

Average heterosis, Heterosis,

Heterobeltiosis,

Standard heterosis, Sorghum.

\section{Article Info}

Accepted: 05 January 2017 Available Online: 10 February 2017
An investigation was done to estimate magnitude of heterosis in sixty six hybrids $\left(\mathrm{F}_{1}\right.$ 's $)$ of Sorghum (Sorghum bicolor (L.) Moench) with respect to yield and its associated components using six newly developed (CGMS) lines and eleven testers. The resulted 66 hybrids and their 17 parents along with two standard checks (CSH 14 - for earliness and CSH 35 - for yield) were evaluated to assess magnitude of heterosis, heterobeltiosis and economic heterosis by using line $\times$ tester analysis at Sorghum Research Unit, Dr. P.D.K.V. Akola 444 001, Maharashtra during Kharif 2015-16. In order to indentify the high yielding kharif sorghum hybrids, promising hybrids $\left(\mathrm{F}_{1}\right.$ 's) were sorted out based on positive significant standard heterosis over the check CSH-35 for grain yield and fodder yield per plant along with other important associated traits. With respect to 66 crosses, total nine promising crosses exhibited significant standard heterosis along with higher mean performance for grain yield per plant i.e. ICS $751 \mathrm{~A} \times$ AKR 530 (44.27\%, $81.78 \mathrm{~g}$ resp.) with significant standard heterosis for fodder yield per plant $(29.16 \%)$, ICS $733 \mathrm{~A} \times \mathrm{AKR}$ $529(26.31 \%, 71.6 \mathrm{~g}$ resp.) along with significant positive standard heterosis for fodder yield per plant (19.15\%) and 1000 seed weight (4.97\%), ICS 279 A × AKR 528 (22.79\%, $69.6 \mathrm{~g}$ resp.) along with significant positive standard heterosis for 1000 seed weight (9.07\%), AKMS 103-8 x AKR 528 (22.74 \%, 69.58 g resp.), AKMS 89 A x AKR 492-1 (21.57\%, 68.92 g resp.), ICS 733 A x AKR 530 ( (21.31\%, 68.77 g resp.) with significant positive standard heterosis for fodder yield per plant (18.66\%), AKMS 89 A x AKR 527 (20.66 \%, 68.4 g resp.), AKMS 103-8-1 A x AKR 525 (19.89\%, 67.96 g resp.) and AKMS 89 A x AKR 524 ( $17.37 \%$, 66.53g resp.). Similarly, one promising cross combination (ICS 279 A x AKR 528) was identified for the early days to $50 \%$ flowering $(-5.82 \%)$ over the check CSH-14.

\section{Introduction}

Sorghum bicolor is genetically suited to hot and dry climate with frequent drought stress, where other crops are difficult to grow. Sorghum is mainly grown as dual purpose crop in India as food (beverages) and forage crop. Therefore, it can deliver a vital role to uplift socioeconomic status of the farmers through development of high yielding cultivars with a reasonable amount of green and dry livestock fodder. Hybrid vigour and its commercial exploitation in Kharif sorghum is an important practice in increasing sorghum production (Rana et al., 1997). However, the exploitation of heterosis on commercial scale 
and the systematic varietal improvement through hybridization are the main tools to increase the kharif sorghum production. The exploitation of heterosis by developing the hybrids is one of the quickest and simpler ways to improving productivity for grain as well as fodder yield. Stephens and Holland (1954) reported for the first time, the use of cytoplasmic genetic male sterility for developing hybrids of sorghum. The availability of cytoplasmic genetic male sterility has put the sorghum hybrids on commercial footing. As a result, a series of hybrids from $\mathrm{CSH}-1$ to $\mathrm{CSH}-35$ and varieties from CSV-1 to CSV-29 have been released at national level under All India Co-ordinated Sorghum Improvement Project in India (AICSIP).

It is a $\mathrm{C}_{4}$ plant with higher photosynthetic efficiency and higher abiotic stress tolerance (Reddy et al., 2009). With the increase in human and animal population and a fragile balance between food supply and demand for it, production of sorghum must be increased to meet the current and future food and fodder needs. It is the most important dual purpose cereal crop for food security.

In this study, an effort was made to identify the high grain yielding cross combinations produced by crossing newly developed parental lines of kharif sorghum. The promising hybrids were sorted out based on positive significant standard heterosis for grain yield.

\section{Materials and Methods}

In the current experiment, the six newly developed cytoplasmic genetic male sterile (CGMS) lines (AKMS 89 A, AKMS 90 A, ICS 279 A, AKMS 103-8 1A, ICS 751 A and ICS 733 A) were crossed with eleven testers (AKR 523, AKR 524, AKR 525, AKR 492, AKR 492-1, AKR 526, AKR 527, AKR 528, AKR 529, AKR 530, and AKR 531 in line $x$ tester fashion in the rabi 2014-15 at Sorghum Research Unit, Dr. Panjabrao Deshmukh Krishi Vidyapeeth, Akola, Maharashtra to produced 66 crosses ( $F_{1}$ 's). Seventeen parents along with their resulting 66 crosses $\left(\mathrm{F}_{1}\right.$ 's) and two standard checks CSH-14 (for earliness), $\mathrm{CSH}-35$ (for yield) were sown during kharif 2015-16 in randomized block design with three replications to estimate the heterosis, over the parents (mid parent heterosis and heterobeltiosis) and checks (standard heterosis) for the various grain yield and yield contributing characters of sorghum. The seed material was planted with inter and intra spacing of 45 and $15 \mathrm{~cm}$ respectively. Recommended package of cultural management practices and plant protection measures were adopted to raise a healthy crop. The data were recorded on five randomly selected plants per plot per replication for eleven characters such as plant height $(\mathrm{cm})$, panicle weight $(\mathrm{g})$, panicle length $(\mathrm{cm})$, panicle breadth $(\mathrm{cm})$, number of primaries per panicle, number of secondaries per panicle, number of grains per panicle, 1000 seed weight (g), grain hardness $\left(\mathrm{kg} / \mathrm{cm}^{2}\right)$, grain yield per plant $(\mathrm{g})$ and fodder yield per plant (g). However, for days to $50 \%$ flowering and days to maturity data were recorded on plot basis. Shoot fly dead heart observation was recorded on percentage basis. The collected data were subjected to analysis to estimate the mid parent heterosis, heterobeltiosis and standard check heterosis with an aim to increase the yield of the kharif grain sorghum.

\section{Results and Discussion}

In present study, analysis of variance (Table 1) revealed the significant variation for most of the characters by various sources except variation due to parents and lines for the shoot fly dead heart (\%) was non-significant. Similarly, non significant variation observed due to lines $v s$. testers in case of panicle length $(\mathrm{cm})$, panicle breadth $(\mathrm{cm})$, fodder 
yield per plant $(\mathrm{g})$ and shoot fly dead hearts (\%). The table 2 indicated that grain yield per plant had greater range of mean performance in crosses $37.67 \mathrm{~g}$ to $81.87 \mathrm{~g}$ as compared to their parents (36.24 to $53.06 \mathrm{~g}$ ). Similarly, in regards to fodder yield per plant, the crosses exhibited the larger range of mean performance from 91.67-245 $\mathrm{g}$ than its parental lines (88.46 to153.37 g) in crosses. In case of Days to $50 \%$ flowering, crosses obtained slightly early flowering range (59.33 to 72.67 days) with respect to their parents flowering days (63.33 to 75 days). Moreover, the wider range in panicle weight was observed $(\mathrm{g})$ in crosses (40.76 to $119 \mathrm{~g}$ ) than its parents ( 37.1 to $75.93 \mathrm{~g}$ ) may due to the higher variation occurred in the number of primaries per panicle and number of secondaries per panicle of the crosses (34.6 to 70.08 and 200.6 to 406.39 respectively) and parents (33.84 to 60.33 and 196.2 to 350.06 respectively). Kalpande et al., (2013) reported in their sorghum studies that the crosses exhibited the wider range of variation (mean performance) for most of the yield contributing characters as compared to their parents.

In response to grain yield per plant, mid parent heterosis, heterobeltiosis, and economic heterosis range from -25.22 to $75.26 \%,-26.86$ to $56.18 \%$ and -33.55 to $44.27 \%$ respectively. Likewise, for fodder yield per plant heterosis (\%) varies from 18.56 to $123.57 \%,-26.67$ to $102.88 \%$ and 36.50 to $69.72 \%$ for mid parent heterosis, heterobeltiosis, and economic heterosis respectively (Table No. 2). Similarly, with regards to days to $50 \%$ flowering broad range of average heterosis range ( -16.82 to $3.35 \%)$, heterobeltiosis $(-18.72$ to $0.47 \%)$ and standard heterosis (-11.44 to $8.46 \%$ ) obtained in the present studies. Crosses had superior heterotic potential for grain yield per plant and fodder yield per plant over its parents (Kalpande et al., 2013).
Average heterosis (over mid parent), heterobeltiosis (over better parent) and standard heterosis (over standard check) were estimated to identify the heterotic potential of the hybrids $\left(\mathrm{F}_{1}\right.$ 's), for all the characters under current experiment (Table 2) and it was observed that out of sixty six crosses, total nine crosses exhibited positive significant standard heterosis over the check CSH-35 for grain yield plant per plant along with other important yield contributing parameters and appeared best promising combination for development of high yielding kharif sorghum hybrids. Along with grain yield, these nine promising cross combinations also showed desirable and significant economic heterosis for some associated component traits (Table 3). However, in case of days to $50 \%$ flowering ICS 279 A x AKR 528 identified as promising cross combination recorded -5.82 $\%$ standard heterosis over the check $\mathrm{CSH}-14$ and recorded promising performance for earliness.

Among the 66 cross combinations, the most excellent cross combination identified was ICS 751 A x AKR 530 with the highest positive significant standard heterosis of $44.27 \%$ for grain yield per plant (Table- 3). Similarly, this cross recorded mid parent heterosis of $75.26 \%$ and heterobeltiosis of $55.04 \%$ for grain yield per plant. Again, cross showed signifcant positive standard heterosis for fodder yield per plant (29.16\%). Similarly, the second promising cross combination was ICS 733 A x AKR 529 with the standard heterosis of $26.31 \%$. Likewise, this cross recorded mid parent heterosis of $58.52 \%$ and heterobeltiosis of $56.18 \%$ for grain yield per plant. Along with previous yield parameters, the hybrid exhibited significantly positive standard heterosis over the check CSH-35 for 1000 seed weight (4.97 $\%)$ and fodder yield per plant $(19.15 \%)$. 


\section{Int.J.Curr.Microbiol.App.Sci (2017) 6(2): 29-37}

Table.1 Analysis of variance of parents and hybrids for various characters under line $\mathrm{x}$ tester analysis

\begin{tabular}{|c|c|c|c|c|c|c|c|c|c|c|c|c|c|c|c|}
\hline $\begin{array}{l}\text { Source of } \\
\text { Variation }\end{array}$ & d.f. & $\begin{array}{c}\text { Days to } \\
50 \% \\
\text { Flowering }\end{array}$ & $\begin{array}{c}\text { Days } \\
\text { to } \\
\text { Maturity }\end{array}$ & $\begin{array}{c}\text { Plant } \\
\text { Height } \\
(\mathrm{cm})\end{array}$ & $\begin{array}{l}\text { Panicle } \\
\text { Weight } \\
\text { (g) }\end{array}$ & $\begin{array}{c}\text { Panicle } \\
\text { Length } \\
(\mathbf{c m})\end{array}$ & $\begin{array}{c}\text { Panicle } \\
\text { Breadth } \\
(\mathrm{cm})\end{array}$ & $\begin{array}{c}\text { Number } \\
\text { of } \\
\text { Primaries } \\
/ \\
\text { Panicle } \\
\end{array}$ & $\begin{array}{l}\text { Number of } \\
\text { Secondaries/ } \\
\text { Plant }\end{array}$ & $\begin{array}{c}\text { Number } \\
\text { of } \\
\text { Grains/ } \\
\text { Panicle }\end{array}$ & $\begin{array}{c}\text { Grain } \\
\text { Yield/ } \\
\text { Plant (g) }\end{array}$ & $\begin{array}{l}1000 \text { Seed } \\
\text { Weight } \\
\text { (g) }\end{array}$ & $\begin{array}{l}\text { Grain } \\
\text { Hardness }\end{array}$ & $\begin{array}{c}\text { Fodder } \\
\text { Yield } \\
\text { /Plant } \\
\text { (g) }\end{array}$ & $\begin{array}{c}\text { Shoot Fly } \\
\text { Dead } \\
\text { Heart } \\
(\%)\end{array}$ \\
\hline & & 1 & 2 & 3 & 4 & 5 & 6 & 7 & 8 & 9 & 10 & 11 & 12 & 13 & 14 \\
\hline Replications & 2 & 0.99 & 3.12 & 15.81 & 6.65 & 3.10 & 0.64 & 3 & 258.8 & 22437.03 & 17.77 & 2.62 & 1.13 & 24.97 & 2.88 \\
\hline Genotypes & 84 & $24.54 * *$ & $18.92 * *$ & $639.67 * *$ & $985.07 * *$ & $37.36^{* *}$ & $1.71 * *$ & $253.2 * *$ & $8520.86 * *$ & $183240 * *$ & $254 * *$ & $39.16^{* *}$ & $3.57 * *$ & $2589.48^{* * *}$ & $4.40^{*}$ \\
\hline Parents & 16 & $25.66^{* *}$ & $12.98 * *$ & $413.69 * *$ & $362.75 * *$ & $14.93 * *$ & $1.31 * *$ & $144.4^{* *}$ & $4863.81 * *$ & $92791.15^{* *}$ & $72.03 * *$ & $70.56^{* *}$ & $4.26 * *$ & $984.94 * *$ & 2.16 \\
\hline Lines & 5 & $45.82 * *$ & $5.65 * *$ & 16.45 & $440.34 * *$ & $34.01 * *$ & $2.64 * *$ & $76.34 * *$ & $2571.81 * *$ & $54046.88 * *$ & $57.21^{*}$ & $116.51 * *$ & $2.85 * *$ & $954.36 * *$ & 1.81 \\
\hline Testers & 10 & $17.95^{* *}$ & $11.95 * *$ & $535.68 * *$ & $291.25^{* *}$ & $6.47 * *$ & $0.77 * *$ & $132.4 * *$ & $4458.06^{* *}$ & $80978.7 * *$ & $64.49 * *$ & $40.84 * *$ & $4.39 * *$ & $1091.57 * *$ & 2.51 \\
\hline $\begin{array}{ll}\text { Lines } & v s \\
\text { Testers } & \end{array}$ & 1 & 1.90 & $59.89 * *$ & $1180 * *$ & $689.69 * *$ & 4.20 & 0.01 & $604.6^{* *}$ & $20381.2 * *$ & $404637 * *$ & $221.5^{* *}$ & $138^{* * *}$ & $10.11 * *$ & 71.63 & 0.34 \\
\hline Hybrids & 65 & $21.67 * *$ & $15.63 * *$ & $521.55^{* *}$ & $923.32 * *$ & $32.85 * *$ & $1.28 * *$ & $239.9 * *$ & $8072.06 * *$ & $174612.5^{* *}$ & $245.4 * *$ & $22.15 * *$ & $3.16^{* *}$ & $2259.38^{* *}$ & $5.01 *$ \\
\hline Error & 168 & 3.89 & 1.77 & 45.96 & 2.93 & 1.33 & 0.25 & 2.77 & 120.18 & 6480.49 & 24.72 & 0.85 & 0.43 & 44.14 & 3.57 \\
\hline
\end{tabular}


Table.2 Range of mean performance and heterosis (\%) for various grain yield and its associated traits

\begin{tabular}{|c|c|c|c|c|c|c|c|}
\hline \multirow{2}{*}{$\begin{array}{l}\text { Sr. } \\
\text { No. }\end{array}$} & \multirow[t]{2}{*}{ Characters } & \multicolumn{2}{|c|}{ Range for mean } & \multicolumn{3}{|c|}{ Range for heterosis $(\%)$ over } & \multirow{2}{*}{$\begin{array}{l}\text { Best significant heterotic } \\
\text { cross over check }\end{array}$} \\
\hline & & Parents & Crosses & Mid parent & Better parent & $\begin{array}{c}\begin{array}{c}\text { Standard } \\
\text { check }\end{array} \\
\end{array}$ & \\
\hline 1 & $\begin{array}{l}\text { Days to } 50 \% \text { flowering } \\
\text { (days) }\end{array}$ & $63.33-75$ & $59.33-72.67$ & -16.82 to 3.35 & -18.72 to 0.47 & -11.44 to 8.46 & ICS 279 A x AKR 528 \\
\hline 2 & Days to maturity (days) & $108-114.33$ & 101.67- 112 & -8.66 to 1.99 & -9.68 to 1.54 & -7.58 to 1.82 & AKMS 89 A x AKR 524 \\
\hline 3 & Plant height (cm) & 141.66- 195 & 143.67- 194 & -13.68 to 32.03 & -23.93 to 29.18 & -17.75 to 11.07 & AKMS 103-8-1A x AKR 530 \\
\hline 4 & Panicle weight (g) & $37.1-75.93$ & 40.76- 119 & -26.08 to 178.73 & -33.71 to 160.91 & -55.15 to 30.95 & ICS 733 A x AKR 529 \\
\hline 5 & Panicle length (cm) & 20.18- 29.18 & 19.18- 34.29 & -26.07 to 53.11 & -29.90 to 46.39 & -32.35 to 20.96 & AKMS 103-8-1 x AKR 492 \\
\hline 6 & Panicle breadth (cm) & $3.91-6.33$ & $4.17-7.03$ & -24.86 to 51.88 & -27.09 to 47.45 & -33.16 to 12.83 & ICS 733 A x AKR 525 \\
\hline 7 & $\begin{array}{l}\text { Number of } \\
\text { Primaries/Panicle }\end{array}$ & $33.84-60.33$ & 34.6- 70.08 & -30.06 to 96.41 & -34.66 to 92.07 & -42.60 to 16.24 & ICS 751 A x AKR 530 \\
\hline 8 & $\begin{array}{l}\text { Number of secondaries } \\
\text { per panicle }\end{array}$ & 196.27- 350.06 & 200.64-406.39 & -30.07 to 96.43 & -34.71 to 92.13 & -42.61 to 16.23 & ICS 751 A x AKR 530 \\
\hline 9 & $\begin{array}{l}\text { Shoot fly dead heart } \\
\text { percentage (at } 28 \text { DAE) }\end{array}$ & 17.86- 21.98 & $16.19-25.58$ & -18.71 to 31.37 & -26.34 to 29.54 & -16.33 to 32.17 & AKMS 90 A x AKR 528 \\
\hline 10 & $\begin{array}{l}\text { Number of Grains/ } \\
\text { Panicle }\end{array}$ & $902.63-1532.41$ & $923.58-1868.81$ & -29.99 to 96.40 & -31.37 to 92.06 & -42.56 to 16.22 & ICS 751 A x AKR 530 \\
\hline 11 & 1000 Seed Weight (g) & $24.28-39.35$ & $30.33-40.18$ & -11.26 to 47.82 & -19.18 to 43.32 & -17.05 to 9.89 & ICS 733 A x AKR 526 \\
\hline 12 & Grain hardness & 7.58- 11.83 & $8.08-12.33$ & -23.08 to 41.12 & -29.58 to 34.02 & -19.83 to 22.31 & ICS 279 A x AKR 492 \\
\hline 13 & Grain yield/ Plant & 36.24- 53.06 & $37.67-81.78$ & -25.22 to 75.26 & -26.86 to 56.18 & -33.55 to 44.27 & ICS 751 A x AKR 530 \\
\hline 14 & Fodder Yield / Plant (g) & $88.46-153.37$ & $91.67-245$ & -18.56 to 123.57 & -26.67 to 102.88 & -36.50 to 69.72 & AKMS 90 A x AKR 527 \\
\hline
\end{tabular}


Table.3 Promising cross combinations along with the significant heterosis in desirable direction for grain yield and its contributing characters

\begin{tabular}{|c|c|c|c|c|c|c|}
\hline \multirow{2}{*}{$\begin{array}{l}\text { Sr. } \\
\text { No. }\end{array}$} & \multirow[b]{2}{*}{ Crosses } & \multirow{2}{*}{$\begin{array}{l}\text { Mean grain } \\
\text { yield/ plant }(\mathrm{g})\end{array}$} & \multicolumn{3}{|c|}{ Heterosis for grain yield/ plant over } & \multirow{2}{*}{$\begin{array}{l}\text { Significant Standard } \\
\text { heterosis for component } \\
\text { characters. }\end{array}$} \\
\hline & & & Mid parent & Better parent & $\begin{array}{l}\text { Standard check } \\
(\mathrm{CSH}-35)\end{array}$ & \\
\hline 1 & ICS 751 A x AKR 530 & 81.78 & $75.26^{* *}$ & $5504 * *$ & $44.27 * *$ & $\begin{array}{l}3,4,5,6,7,8,10 \\
12\left(14.88^{* *}\right) \\
14\left(29.16^{* *}\right)\end{array}$ \\
\hline 2 & ICS 733 A x AKR 529 & 71.6 & $58.52 * *$ & $56.18^{* *}$ & $26.31 * *$ & $\begin{array}{l}3,4,5,11(4.97 *), 14 \\
(19.15 * *)\end{array}$ \\
\hline 3 & ICS 279 A x AKR 528 & 69.6 & $38.95^{* *}$ & $35.13^{* *}$ & $22.79^{* *}$ & $7,8,10,11(9.07 * *)$ \\
\hline 4 & AKMS 103-8-1A x AKR 528 & 69.58 & $58.47^{* *}$ & $42.93^{* *}$ & $22.74 * *$ & $5,6,7,8,11(9.21 * *)$ \\
\hline 5 & AKMS 89 A x AKR 492-1 & 68.92 & $46.30^{* *}$ & $37.10^{* *}$ & $21.57^{* *}$ & $7,8,10$ \\
\hline 6 & ICS 733 A x AKR 530 & 68.77 & $39.50^{* *}$ & $30.36^{* *}$ & $21.31^{* *}$ & $5,7,8,10,14\left(18.66^{*}\right)$ \\
\hline 7 & AKMS 89 A x AKR 527 & 68.4 & $70.61^{* *}$ & $55.66^{* *}$ & $20.66^{* *}$ & $7,8,10$ \\
\hline 8 & AKMS 103-8-1A x AKR 525 & 67.96 & $54.11 * *$ & $38.52^{* *}$ & $19.89^{* *}$ & $3,5,6,7,8,14\left(19.65^{* *}\right)$ \\
\hline 9 & AKMS 89 A x AKR 524 & 66.53 & $43.41 * *$ & $36.21 * *$ & $17.37 * *$ & 7,8 \\
\hline
\end{tabular}

* significant at $5 \%$ level of significance $\quad * *$ - significant at $1 \%$ level of significance

Note: 1: Days to $50 \%$ flowering $\quad 2$ : Days to maturity 4: Panicle Weight $(\mathrm{g}) \quad$ 5: Panicle length $(\mathrm{cm})$

7: Number of primaries / panicle 8: Number of secondaries / panicle 9: Shoot fly Dead heart percentage 21(DAE)

10: Number of Grains/ Panicle 11: 1000 Seed Weight (g)

13: Grain Yield/ Plant (g)
3: Plant height $(\mathrm{cm})$

12: Grain Hardness 
Int.J.Curr.Microbiol.App.Sci (2017) 6(2): 29-37

Fig.1 Graphical presentation of promising nine cross combinations for the various heterosis

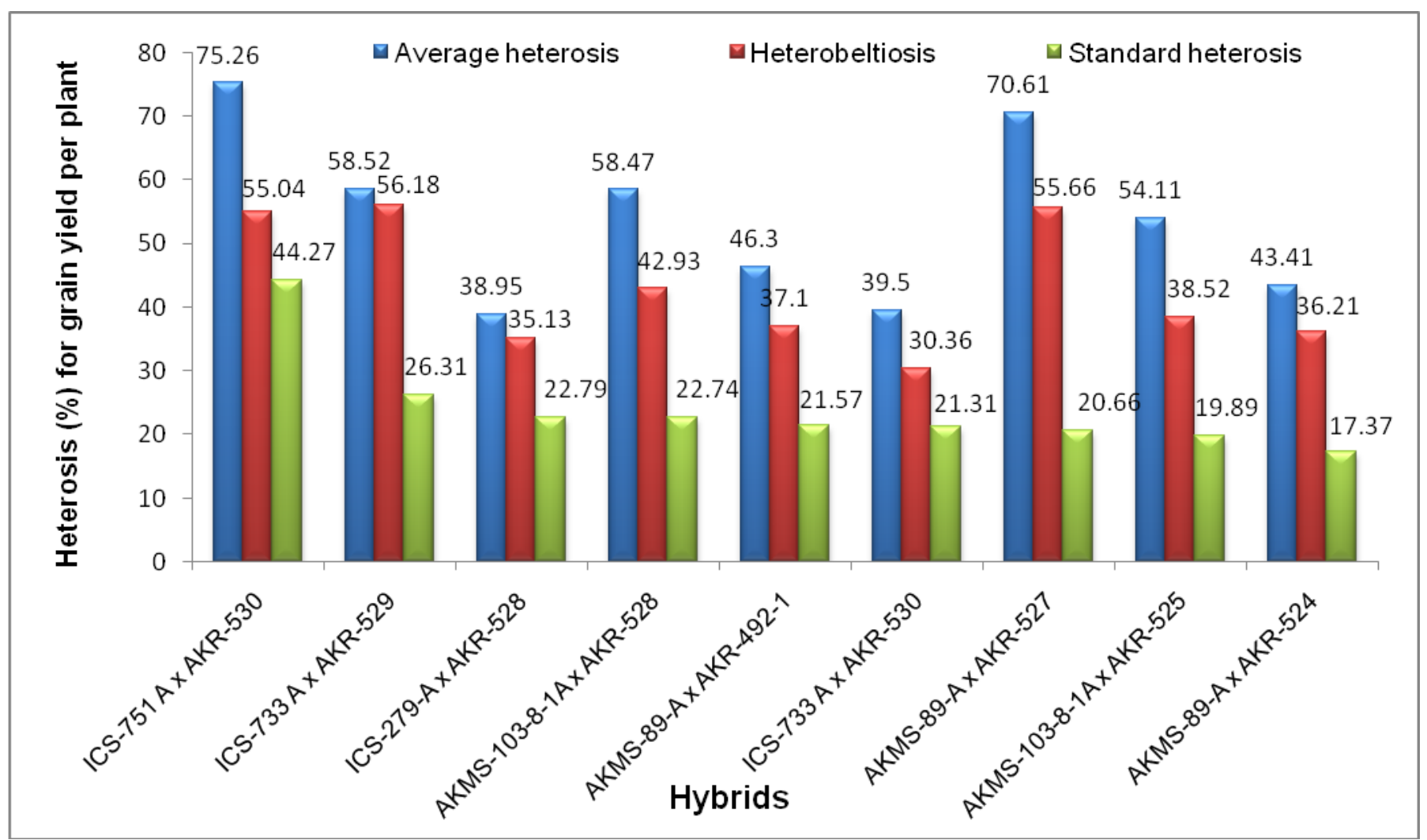


The third best cross combination was ICS 279 A $\mathrm{x}$ AKR 528 with standard heterosis of $22.79 \%$, mid parent heterosis of $38.95 \%$ and the heterobeltiosis of $35.13 \%$ for grain yield per plant. With respect to 1000 seed weight, the hybrid noted significant positive standard heterosis at $9.07 \%$ over the check CSH-35. The fourth top ranking cross combination was AKMS 103-8 1A x AKR 528 with the standard heterosis of $22.74 \%$, mid parent heterosis of $58.47 \%$ and the heterobeltiosis of $42.93 \%$ for grain yield per plant. Similarly, the cross showed significant desirable standard heterosis over the check CSH-35 for 1000 seed weight $(9.21 \%)$. The fifth excellent cross combination was AKMS 89 A $\mathrm{x}$ AKR 492-1 with the positive significant standard heterosis of $21.57 \%$ along with the average heterosis of $46.30 \%$ and the heterobeltiosis of $37.10 \%$ for grain yield per plant. Besides this cross combinations, another four crosses (ICS 733 A x AKR 530, AKMS 89 A x AKR 527, AKMS 103-8 A x AKR 525, AKMS 89 A x AKR 524) showed positive and significant standard heterosis over the check CSH-35 $(21.31 \%, 20.66 \%$, $19.89 \%$ and $17.37 \%$ resp.), average heterosis $(39.50 \%, 70.61 \%, 54.11 \%$, and $43.41 \%$ resp.), heterobeltiosis $(30.36 \%, 55.66 \%$, $38.52 \%$ and $36.21 \%$ resp.) for grain yield per plant. This data set clearly indicated that these crosses can be very well exploited using heterosis breeding for development of high yielding kharif sorghum hybrids. Kalpande et al., (2015), Jhansi Rani et al., (2008); Mahdy et al., (2011); Hariprasanna et al., (2012); Prabhakar et al., (2013) and Ghorade et al., (2014) also reported high heterosis in the promising crosses for grain yield in sorghum.

In conclusion, the results of the current investigation indicated that potential amount of standard heterosis was evident for grain yield per plant along with considerable amount of mid parent and better parent heterosis in nine promising cross combinations. The most excellent five heterotic cross combinations identified on the basis of highest significant positive standard heterosis (Figure 1) were ICS $751 \mathrm{~A} \times \mathrm{AKR}$ 530 (44.27\%), ICS 733 A $x$ AKR 529 (26.31\%), ICS 279 A x AKR 528 (22.79\%), AKMS 103-8 1A x AKR 528 (22.74\%) and AKMS 89 A x AKR 492-1 (21.57\%). Along with grain yield per plant, most of the promising cross combinations recorded advantageous and significant standard heterosis for some of the yield contributing characters. Likewise, ICS 279 A x AKR 528 identified as promising cross combination recorded $-5.82 \%$ standard heterosis over the check $\mathrm{CSH}-14$ in case of days to $50 \%$ flowering. These nine crosses need to be evaluated further by their testing on large scale multilocation and multi season trials to find out the most stable genotype for further exploitation.

\section{References}

Ghorade, R.B., Kalpande, V.V. and Bhongle, S.A. 2014. SPH-1635- A dual purpose high yielding kharif sorghum hybrid. Int. J. Agri. Sci., 10(1): 134-137.

Ghorade, R.B., Kalpande, V.V., Bhongle, S.A., and Boratkar, M.V. 2013. Heterosis studies involving newly developed parents of kharif sorghum. Plant Archives, 13(2): 743-745.

Hariprasanna, K., Rajendrakumar, P.and Patil, J.V. 2012. Parental selection for high heterosis in sorghum (Sorghum bicolor (L.)Moench)-Combining ability, heterosis and their relationship. Crop Res., 44(3):400-408.

Jhansi Rani, K., Rao, S.S. and Ganesh, M. 2008. Heterosis and inbreeding depression in rabi sorghum (Sorghum bicolor (L.) Moench). J. Res., ANGRAU. 36(4):61-67.

Mahmoud, A.M. 2011. The effects of environment on combining ability and 
heterosis in grain sorghum (Sorghum bicolor (L.) Moench). Asian J. of crop Sci., 3(1):1-15.

Prabhakar, Elangovan, M., and Bahadure, D.M. 2013. Combining ability of new parental lines for flowering, maturity and grain yield in rabi sorghum. Electronic J. Plant Breeding, 4(3): 1241-1218.

Rana, B.S., Swarnlata Kaul and M.H. Rao. 1997. Impact of genetic improvement on sorghum productivity in India. Pages 142-165 in the Proceedings of the Int. Conference on Genetic Improvement of Sorghum and Pearl millet, 22-27 September 1996, Holiday Inn Plaza, Lubbock, Texas.

Reddy, B.V.S., Ramesh, S., Reddy, P.S. and Kumar, A.A. 2009. Genetic Enhancement for Drought Tolerance in Sorghum. Plant Breed. Rev., 31: 189222.

\section{How to cite this article:}

Vikas Mangal, R.B. Ghorade, Dipali P. Thakare, V.V. Kalpande and Dange, A.M. 2017. Exploitation of Heterotic Combinations for Grain Yield and Yield Associated Components in Kharif Sorghum. Int.J.Curr.Microbiol.App.Sci. 6(2): 29-37. doi: http://dx.doi.org/10.20546/ijcmas.2017.602.004 